\title{
The mediating role of perceived administrative support for the effect of job motivation on organizational identification
}

\author{
Gökçe Özdemir \\ Department of Education in Nizip, Gaziantep University, Turkey
}

\begin{tabular}{l}
\hline Article Info \\
\hline Article history: \\
Received Dec 10, 2019 \\
Revised Jun 2, 2020 \\
Accepted Jul 15, 2020
\end{tabular}

\section{Keywords:}

Job motivation

Organizational identification

Perceived administrative support

Teacher

\begin{abstract}
In this study, the mediating role of perceived administrative support for the effect of teachers' job motivation on their organizational identification perceptions was investigated. For this purpose, in mind, the opinions of 320 kindergarten teachers in 304 schools from 13 different school districts of Şahinbey/Gaziantep were received. However, 233 scales were taken into consideration. The research data were collected through Job Motivation Scale (JMS), Organizational Identification Scale (OIS) and Perceived Administrative Support Scale (PASS). Descriptive statistics, correlation analysis, multiple regression analysis, and path analysis were used in data analysis. Analysis results revealed that the job motivation perceptions of teachers were high. In addition, it was revealed that the participants also had high scores for organizational identification and perceived administrative support. Correlation analyses yielded positive, moderate and significant relationships between the research variables. Path analysis uncovered that perceived administrative support had a "partial mediating" role for the relationship between job motivation and organizational identification. Based on research findings, it was concluded that the effect of job motivation on teachers' identification with their organizations was realized through perceived administrative support, albeit partially.
\end{abstract}

This is an open access article under the CC BY-SA license.

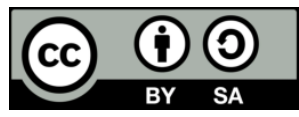

Corresponding Author:

Gökçe Özdemir,

Department of Education in Nizip,

Gaziantep University,

Gaziantep, Turkey.

Email: gozdemir382@gmail.com

\section{INTRODUCTION}

The efforts to determine the factors affecting organizational behaviours have become a requirement in an increasingly competitive environment for the organizations that have a dynamic structure in order to increase the employee performance. In particular, ensuring the employees' integration with the organization through improving their sense of organizational commitment and providing their integration with the organization is important in achieving organizational goals [1]. The way individuals feel and belong to the organization they are members of is shaped according to their individual attitudes and beliefs about the organization [2]. Therefore, it can be alleged that the individuals with a high level of organizational identification will feel loyal to the organization through defending the aims and principles of the organization. Hall, Schneider \& Nygren stated that organizational identification will create an emotional bond between the individual and the organization as a result of the individuals' adopting the values, aims and objectives of the institutions they work for as if their own values, goals and objectives [3]. That's why, the employees experience stronger and more permanent identification when they identify their individual 
goals with those of the organizations they work for. Within this framework, it will be possible for organizations to understand the mechanisms directing the employees' attitudes and behaviours towards work and determine the employees' perceptions about the organization so that they can create human resources working for the organization's own purposes and direct them desirably [1]. It is a general assumption that the employee who identifies himself/herself with the organization s/he works for will make every effort to achieve the organizational goals and defend his/her organization in every occasion. All these behaviours will also increase organizational productivity. Meanwhile, the creation of work environment to be desirable by the employees, administrative support and job motivation are considered to be significant organizational behaviours in order to achieve organizational identification. That's why; human beings are the most fundamental elements of carrying out the organizational activities in accordance with the objectives. It can be claimed that the change of perspective with regard to working people particularly with the transition to mass production and the reduction of the need for human factor caused the job satisfaction and motivation of employees to decrease. Motivation, a dynamic process that keeps people alive through mobilizing them, increases the wishes and desires of individuals in achieving pre-determined individual and organizational goals [4]. As the motivated individual will enjoy doing the job, the performance and sense of self-integration will also increase. Sercan also noted that individuals with high job motivation will have higher levels of achieving their goals [5].

Job motivation is an internal process of creating individual willingness and mobilizing the individuals for the realization of organizational goals, depending on the fulfilment of individual needs [6, 7]. Motivation can be defined as the forces to conduct positively towards work and maintain them with the effect of internal and external parameters. Motivation, which is an important determinant of employee performance, has contributions of doing the best, producing quality services, being happy to be the part of the organization they work for and developing positive business attitudes. Motivation has two important features. Primarily, motivation is something related to the person, and secondly, it is an observable behaviour [8]. Although there have been studies on motivation since the 1900s, the research after 1930s have increased because of the effect of motivation on organizational psychology and theories approaching motivation from different perspectives have been put forward [9, 10]. The theories attempting to explain job motivation are divided into content and process theories. Content theories focus on individual needs and try to identify the factors influencing one's behaviours [11]. These theories argue that the most important determinant in providing employee motivation is the created work environment. Process theories, on the other hand, focus on the factors leading to the initiation and maintenance of behaviour. These theories focus specifically on the psychological processes underlying the behaviours [9]. It can be said that both content and process theories are mainly focused on increasing employees' happiness and desire of doing business in the working environment. If the motivation elements are created to keep the employees' willingness to do business alive, people will feel comfortable, regard themselves as a worth for the organization, and thus they develop organizational integration. Similarly, in their study, Christen, Iyer \& Soberman found that job motivation had a positive effect on the variables such as employee performance, commitment and identification while Houston asserted that motivation was effective on the attitudes and behaviours towards work [12, 13].

Patchen firstly used the concept of organizational identification to describe the similarity, loyalty and membership between the employee and the organization [14]. From then, it has not been possible to reach a consensus on the definitions although many of them have been offered for organizational identification. According to the common aspects of the definitions, identification is defined as the employee's considering himself/herself with his/her organization as a whole, and matching the individual and organizational goals with each other to a large extent. Identification is one of the concepts based on social identity theory [15]. Social identity theory, which is defined as the attitudes within a group, is described as the self-concept that develops as a result of the individual's membership in a group or groups and the value and emotional importance someone attaches to this membership. Mael \& Ashforth, voiced that organizational identification has a cognitive structure unlike emotional and behavioural aspects, it becomes meaningful with the presence of groups and classifications and the individuals define themselves and their organizations as a whole to increase their self-esteem because of their tendency to perceive their social identities more positively [16]. According to Buchanan, identification is an affective commitment of an individual to the organization in determining his/her own role in the realization of the aims and values of the organization. For this reason, in identification, individuals are expected to do their actions voluntarily while doing their job in the organization, believe in the aims and values of the organization and tend to maintain his/her membership of the organization. In the process of identification, the values, organizational goals and beliefs of the organization, that is the organizational culture, will be internalized by the individual, and thus the identification is realized [17]. The employees' perception of identification with their organizations have an important place within the areas of organizational scientists due to affecting employee performance, being a determinant of motivation and supporting human resources policies [18]. Therefore, we can say that 
the individuals with high organizational identification will prefer the expressions they use for themselves to describe their organization. Identification is an important concept for organizations. That's why, identification is not only an integration of the individual with the institution in which s/he works, but also an indicator of organizational development activities, organizational strategies and individual or organizational socialization. Identification, as an organizational phenomenon, is the basic structure for organizations and constitutes the infrastructure for many organizational behaviors. In the literature review about organizational identification, it was found to be associated with trust, commitment, motivation, job satisfaction, administrative support and job performance. It is observed that the achievement motive of the employees who especially supported by their managers has increased, they become more creative, their courage and responsibility have enhanced and their skills to build positive relationships have improved [19].

The concept of administrative support, which refers to positive business relationship between the manager and the employees, is defined as managers' allowing to emerge new talents, share authority, provide feedback on organizational activities, and support the development of their existing skills while engaging in activities for employees to acquire new skills [20, 21]. Employees who feel that they receive administrative support will feel worthy, their motivation and willingness to do business will increase and they will strive more for organizational purposes [22]. Administrative support affects many organizational behaviors such as employee performance, identification, commitment and job satisfaction. Perceived administrative support is based on social change, leader-member exchange, and psychological contract theories. According to the theory of social change, subordinates who are financially and morally supported by their managers have an increased level of organizational commitment and satisfaction with the work environment as they have more intimate and sincere ties with their managers [23, 24]. Leader-member exchange theory is defined as a dual process focusing on the relationship between leader and his/her subordinates. According to this theory, high quality relationship, high level of interaction, high level of trust and respect, mutual influence and trust emerge as the roles of organization members depending on their interaction with their superiors [25, 26]. Finally, psychological contract theory, which is a part of social change theory, is defined as the unwritten change of mutual expectations between employees and employers [27]. Psychological contract is the attitude of employees towards the job and the employers and the employers' attitude towards the job and the employees [28, 29]. Manager behaviors have positive or negative effects on employees. Therefore, managers need to be aware of the impact they have on their employees and exhibit supportive behaviors. Also, it should not be ignored that employees' feeling of worthwhile and recognizing that they are supported by their managers will create willingness to do business through increasing their motivation. According to Babin \& Boles, encouraging, supporting and dealing with the problems related to the employees' work-related efforts by the manager will contribute positively to their organizational identification and job performance [30]. Regarding motivation, which is a complex process, it is very important that the managers of the organization know what they need to do in this process, understand the reasons of behaviors and realize that everyone has different characteristics and needs. Herzberg, stated that superiors should give their subordinates the opportunity to show their talents and support them to succeed in order to increase employee motivation [31]. That's why, the increase in employee performance, the integration of individual and organizational values and productive working depends on job satisfaction and motivation [32].

In the profession of teaching, which requires sacrifice and high professional commitment, the emotions and excitement of teachers must also be kept alive. The continuity of teachers' willingness and happiness, especially their motivation, may contribute to the feeling of being comfortable in the work environment, doing the job with enthusiasm, feeling that they are worthwhile, and thus integrating with the organizations. In this way, they can regard themselves as the part of both their job and their work environment. That's why, not only meeting the educational needs, but also knowing that they are allocated responsibility and authority, feeling important and considering that they are accepted by their colleagues will increase the motivation of the employees, and so make more efforts to realize the organizational goals [33]. It is thought that this study will give teachers the opportunity to become aware of their attitudes towards the institutions they work for, and will provide data on the effects of teacher motivation and administrative behaviors on the employees. It is believed that the research results will guide the planning of activities while making organizational development plans to increase the productivity of employees. In addition, it is expected that the study will contribute to the literature as there is no three-variable study related to job motivation, organizational identification and perceived administrative support. Based on these, the aim of the research was to determine teachers' opinions about job motivation, organizational identification and perceived administrative support and to find out whether job motivation has a significant effect on organizational identification through perceived administrative support. 


\section{RESEARCH METHOD}

\subsection{Research design}

The study was designed as a quantitative research that can be measured, counted, and often expressed in concrete words. In the study, relational survey model, one of the quantitative research methods, was used. Relational survey research are those in which the relationship between two or more variables is determined according to the opinions of participants [34]. The present study was designed in a relational survey model as it was attempted to reveal the relationships between job motivation, organizational identification and perceived executive support.

\subsection{Study group}

The study group of the study consisted of 320 kindergarten teachers in 304 schools located in 13 different school districts in Şahinbey/Gaziantep. No sampling was taken in the study and the scales were applied to all 320 kindergarten teachers in 304 schools. 50 of the scales were not returned and 37 of them were excluded as they were not filled in properly. A total of 233 scales were taken into consideration for analysis. $26(11.2 \%)$ of the participants were male and $207(88.8 \%)$ were female. Of the participants, 16 $(6.9 \%)$ were aged 24 and under, 74 (31.8\%) were between 25-30 years old, 95 (40.8\%) were between 31-40 years old, and $48(20.6 \%)$ were 41 years and older. In addition, $16(6.9 \%)$ of the participating teachers had 1-year, $74(31.8 \%)$ had 2-5 years, $95(40.8 \%)$ had 6-10 years, and $48(20.6 \%)$ had 11 and more years of professional seniority.

\subsection{Data collection instruments}

The research data were collected through job motivation, organizational identification and perceived administrative support scales.

\section{a. Job motivation scale}

The scale developed by Y1lmaz, consists of 4 dimensions and 14 items [35]. The JMS is a 5-point Likert-type data collection instrument ranging from "not satisfied at all' to 'completely satisfied'. In his study, Y1lmaz found the Cronbach's alpha for the overall scale as .81, for the sub-dimension of team cohesion as .71 , for the sub-dimension of job integration as .69 , for the sub-dimension of corporate commitment as .66, for the sub-dimension of personal development as .63. Within the scope of this study, Cronbach's alpha of the overall scale was estimated to be .96 , the sub-dimension of team cohesion .87 , the sub-dimension of job integration .85 , the sub-dimension of corporate commitment as .83 , the sub-dimension of personal development .83 .

\section{b. Organizational identification scale}

The scale, which was adapted to Turkish by Loğa, consists of 11 items in one dimension [36]. The OIS is a 5-point Likert-type data collection instrument with the points between 'totally disagree' and 'totally agree'. While the Cronbach's alpha of the original scale was .87 , it was found to be .86 for the present study.

\section{c. Perceived administrative support scale}

The scale, which was developed by Kottke \& Sharafinski (1988), and translated into Turkish and adapted to educational settings by Özdemir, is composed of one dimension and 14 items [37]. The PASS is a 5-point Likert-type data collection tool ranging from 'strongly disagree' to 'strongly agree'. The Cronbach's alpha coefficient of the scale estimated as .96. Based on this study, Cronbach's alpha was found to be .94 .

\subsection{Data analysis}

SPSS 22.0 software package was used for the analysis of research data and LISREL 8.80 was preferred for structural equation modelling. Frequency and percentage distributions were estimated to describe the demographic characteristics of the participants. The assumptions of the relevant method should first be tested in order to determine whether statistical methods are suitable for the data under investigation. Therefore, the assumptions of regression analysis were checked in the first place. One of the assumptions of the analysis is that dependent and independent variables should be continuous ones at least on interval scale and distribute normally [38]. The measures of central tendency and skewness and kurtosis coefficients were examined to investigate whether the predictor and predicted variables show normal distribution. As a result of the analysis, the skewness coefficient of the organizational identification was found to be -. 270, and its kurtosis coefficient -. 278, the skewness coefficient of the work motivation was found to be -. 261, and its kurtosis coefficient -. 259, the skewness coefficient of perceived administrative support was found to be -. 880, and its kurtosis coefficient -. 127. As skewness and kurtosis coefficients are within the values of \pm 1 , it can be claimed that the data show normal distribution [38]. Another assumption of multiple regression 
analysis is to examine whether the relationship between the predictor variables and the predicted ones is linear. The scatter plot was drawn to control this assumption. When the linear graph for the presence of linear relationship was examined, it was concluded that the scatter plot created for the standardized residual values and the standardized predicted values defined a linear relationship and the normal distribution curves showed a normal distribution. In addition, variance inflation factors (VIF) and tolerance values were examined to determine the correlation between the predictor variables. As there were no estimations large than 10 among VIF values (3.360) and less than 0.2 among tolerance values (.298), it can be asserted that there was no multiple correlation [39]. Mahalanobis distances were also calculated as the outliers of data would impair the compatibility of the regression model with the required model in the regression analysis. In the study, since the number of independent variables was two and the values with Mahalanobis distance over 9.210 for $\mathrm{p}=0.01$ were outliers, no data deletion was performed as there were no estimations more than 9.210 in the data set. Following these processes, correlation analysis was performed for multi-collinearity between the variables. After the correlation analysis, a regression analysis was conducted by creating a 2-stage model to test the role of perceived administrative support in the effect of job motivation on organizational identification. In the analysis, the organizational identification factor was included in the equation in the first step and its effects were controlled. In the second step, hierarchical multiple regression analysis was conducted to measure the effects of perceived administrative support variable. After the regression analysis, the theoretical model for the relationships between job motivation, organizational identification and perceived administrative support was tested with the structural equation modelling using LISREL 8.80 program.

\section{RESULTS AND DISCUSSION}

After descriptive statistics, correlation coefficients between variables were estimated to determine teachers' opinions on job motivation, organizational identification and perceived administrative support. The findings are submitted in Table 1. As can be seen in Table 1, teachers' opinions on job motivation $(\overline{\mathrm{X}}=3.54)$, organizational identification $(\overline{\mathrm{X}}=3.94)$ and perceived administrative support $(\overline{\mathrm{X}}=3.82)$ are at 'high' level. The scores between 3.40 and 4.19 on a 5-point Likert-type scale correspond to "high" level [40]. Based on these findings, it can be affirmed that teachers' opinions about job motivation, organizational identification and perceived administrative support are in positive manner. In the present century, job motivation and administrative support are considered to be essential organizational behaviours in increasing the employee performance in the workplaces and in identifying themselves as part of the work done, in other words, in identifying themselves with their jobs [41]. According to the finding, it was concluded that teachers' perception of job motivation was high. High job motivation of teachers can be interpreted as they do their job lovingly and they have job satisfaction. Çalış, draws attention to the importance of teacher motivation in achieving success in education and has confirmed that teachers' job motivation is high in his study [42]. Job motivation is a concept that cannot be ignored in terms of achieving organizational objectives and increasing the quality of production, service and productivity [43]. Depending on the data obtained from the research results, it is possible to say that teachers' perceptions of organizational identification were also high. According to this finding, it can be claimed that teachers identify themselves with their schools and regard themselves as the representatives of their schools. In addition, employees who identify themselves with the organization they work for internalize organizational values and beliefs and exhibit consistent behaviours [44, 45]. Another finding obtained from the study was that teachers' perceptions related to be supported by their administrators were high. Teachers develop different attitudes depending on the appreciation of what they do for the school by their administrators, and the attitudes developed by the teachers differ according to their perceptions regarding to be supported and valued by their managers [46]. Based on this result, it can be stated that teachers are satisfied with their administrators, their needs and expectations are met by their superiors and there are good positive relationships between them.

Table 1. Descriptive statistics for variables and correlation matrix showing the relationship between variables

\begin{tabular}{lccccc}
\hline & $\overline{\mathrm{X}}$ & $\mathrm{SD}$ & Job motivation & Identification & Administrative support \\
\hline Job motivation & 3.54 & .742 & 1 & & \\
Identification & 3.94 & .625 & $.390^{*}$ & 1 & \\
Administrative support & 3.82 & .687 & $.319^{*}$ & $.482^{*}$ & 1 \\
\hline * $<$ <.01 & & & & &
\end{tabular}

As can be seen in Table 1, there is a positive, moderate and significant relationship between job motivation and organizational identification $(r=.39, \mathrm{p}<.01)$. This shows that teachers have positive thoughts about their job, so there is a positive and significant relationship between the way they define themselves and

The mediating role of perceived administrative support for the effect of job motivation ... (Gökçe Özdemir) 
their organizations. In addition, depending on the fact that the participating group is composed of kindergarten teachers who need to love, sacrifice and labour more than other subject matter teachers, it can be asserted that the teachers love their job, hence they have developed positive attitudes towards their jobs and the institutions they work for, and they regard the success of the institution as their own achievements. Similarly, there is a positive, moderate and significant relationship between job motivation and perceived administrative support $(\mathrm{r}=.31, \mathrm{p}<.01)$. Kurt, proved that perceived administrative support significantly affected job performance and accordingly job motivation in his study examining the relationship between perceived social support and job performance, and Demirhan, Kula \& Karagöz also found a positive and significant relationship between administrative support, job satisfaction and job performance [47, 48]. Finally, there is a positive, moderate and significant relationship between perceived administrative support and organizational identification $(r=.48, \mathrm{p}<.01)$. Eisenberger, Huntington, Hutchison \& Sowa, noted that the more the appreciation, respect and relationship needs of the employees are met by the managers and their efforts are rewarded, the higher their perception of support will be [49]. In general, the findings indicate that there is a moderate and positive relationship pattern among the variables of the present study. Based on the expression that values less than 0.30, those between $0.30-0.69$ and those more than 0.70 can be interpreted as low, medium and high level of relationship respectively for the relationships between the variables, moderate and positive relationships were observed between all the variables [50]. Therefore, it can be asserted that teachers feel their administrators ready when they need them, their own interests are taken into consideration for the decisions about themselves, their contributions to the school are believed to be noticed by the administrators, and they internalize the values of the institution depending on these factors.

Multiple regression was performed to determine whether the variables of job motivation and administrative support predict organizational identification. The results of regression analysis are presented in Table 2. As seen in Table 2, job motivation is a significant predictor of organizational identification $(\beta=.39, \mathrm{p}<.01)$ and $30.2 \%$ of organizational identification is explained through job motivation $\left(\mathrm{R}^{2}=.302\right.$, $\mathrm{p}<.01)$. Job motivation is a significant predictor of perceived administrative support $(\beta=.55, \mathrm{p}<.01)$ and $46 \%$ of perceived administrative support is explained through job motivation ( $R 2=.460, \mathrm{p}<.01)$. Analysis results demonstrate that perceived administrative support is a significant predictor of organizational identification $(\beta=.29, \mathrm{p}<.01)$ and $20.5 \%$ of organizational identification is explained through perceived administrative support $(\mathrm{R} 2=.205, \mathrm{p}<.01)$. In addition, it is observed that the effect of job motivation on organizational identification proceeds with the inclusion of perceived administrative support, but the effect coefficient and significance level decreases $(\beta=.31, \mathrm{p}<.01)$ and $35.2 \%$ of organizational identification is explained through job motivation and perceived administrative support $(\mathrm{R} 2=.352, \mathrm{p}<.01)$. It can be alleged that perceived administrative support is a partial mediator variable due to the decrease in the effect coefficient and the significance level of job motivation after the inclusion of perceived administrative support to the analysis. However, the significance of the decrease in beta values was analyzed through Sobel Test in order to make clear whether the mediating effect was statistically significant or not. Sobel test results were $\mathrm{Z}=3.026$, $p=0.0024$. The significance of Sobel Tests confirms the existence of the partial mediator effect of perceived administrative support variable between these variables. Depending on this result, it can be stated that the individuals' perceptions of organizational identification will also increase together with high job motivation, and perceived administrative support will make positive contributions to increase organizational identification perception, albeit partially. In support of this finding, Celep predicts that organizational identification is related to job satisfaction, motivation, performance, loyalty to the organization, commitment and collaborative behaviours [51]. In addition, the employees who integrate their own goals with the organizational ones are less likely to quit their jobs and exert extra effort and high performance for their organizations [52]. In particular, it is possible to say that employees who feel the support of their managers will do their jobs with high motivation, and thus their productivity and work-oriented efforts will increase [53]. In other words, the employees will do their job lovingly and will not avoid taking responsibility about the work as the perception of high organizational identification will create happiness in people. That's why, the employees will consider the work they do for the organization as their own business, they will view the objectives of the organization as their own ones and they will work effectively and highly motivated to achieve these objectives of the organization as a result of organizational identification [54].

Table 2. Structural models between the variables

\begin{tabular}{cccccc}
\hline Model & Variables & $\beta$ & $\mathrm{t}$ & $\mathrm{p}$ & $\mathrm{R}^{2}$ \\
\hline Job motivation & Identification & .39 & 4.32 & $.000^{* *}$ & .302 \\
Job motivation & Perceived administrative support & .55 & 9.12 & $.000^{* *}$ & .460 \\
Perceived administrative support & Identification & .29 & 3.77 & $.000^{* *}$ & .205 \\
Job motivation Administrative support & Identification & .31 & 3.92 & $.002^{* *}$ & .352 \\
\hline *p $<.05, * * \mathrm{p}<.01, * * * \mathrm{p}<.001$ & & & & &
\end{tabular}

Int. J. Eval. \& Res. Educ. Vol. 9, No. 3, September 2020: 539 - 547 
The theoretical model for the relationships between job motivation, organizational identification and perceived administrative support was tested through the structural equation modelling. The analysis results of the structural equation model are given in Figure 1. As can be seen in Figure 1, the effect of job motivation on organizational identification decreased after the inclusion of perceived administrative support variable into the model. In the structural equation model analysis, the effect of dependent and independent variables on each other was analysed in the first place as in multiple regression analysis (0.44). Then, perceived administrative support was added to the model as a mediator variable. With the inclusion of the mediator variable to the model, the effect of job motivation on organizational identification has decreased $(0.26)$. The resulting decline indicates that perceived administrative support is a partial mediator variable in this relationship. The goodness of fit indices of the model in which the mediation effect is tested also in favour of

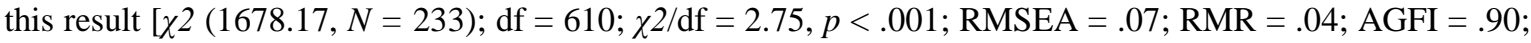
$\mathrm{GFI}=.92 ; \mathrm{CFI}=.98 ; \mathrm{IFI}=.98 ; \mathrm{NFI}=.97 \mathrm{]}$. Based on the expression of Schermelleh-Engel \& Moosbrugger in that RMSEA $<0.10$ and $2 \leq \chi 2 / \mathrm{df} \leq 3$ refer to "acceptable fit", it is observed that the model has a good fit according to the overall values of model [55].

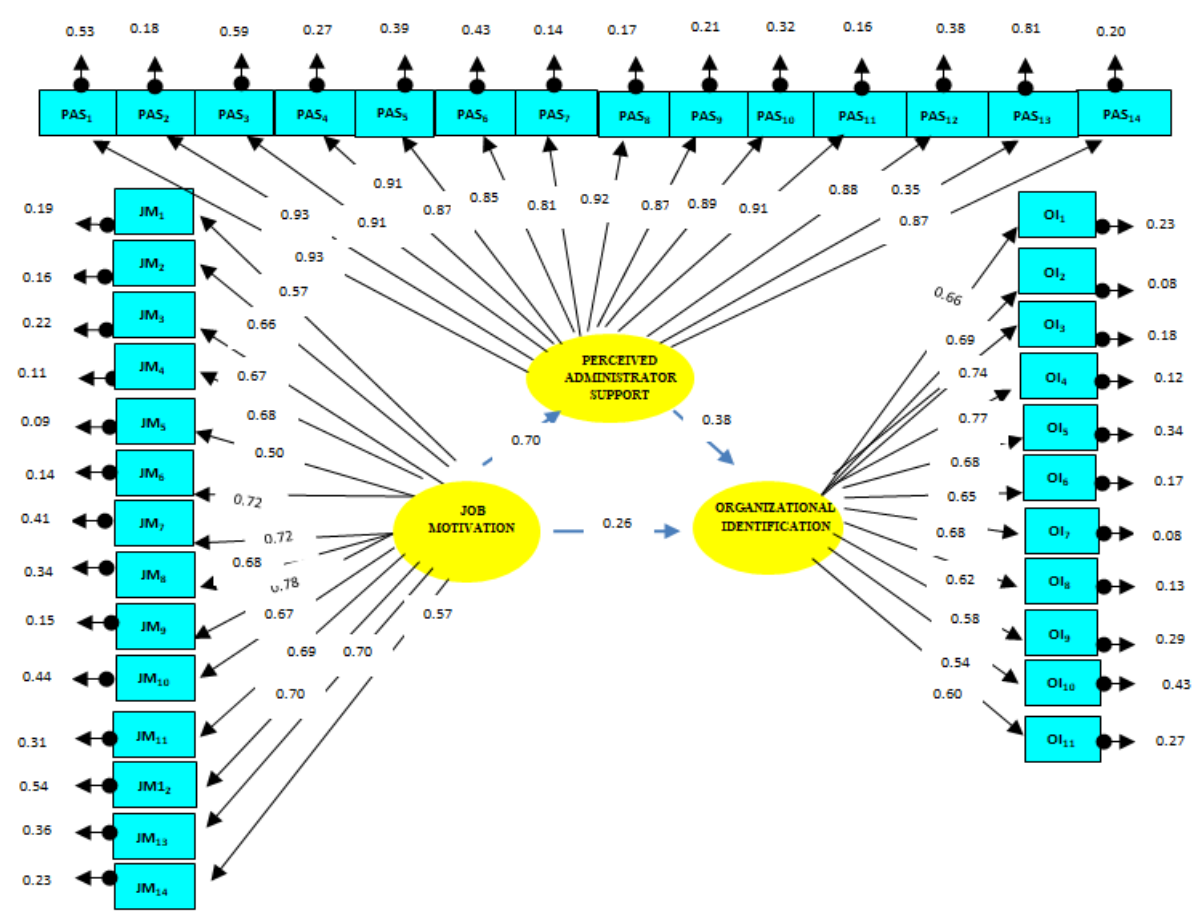

Chi-Square $=1678.17, \mathrm{df}=610, \mathrm{p}$-value $=0.00000$, RMSEA $=0.076$

Figure 1. The results of structural equation model

\section{CONCLUSION}

Job motivation, organizational identification and perceived administrative support perceptions are significant notions for both organizations and employees as they are the reflection of the employees' relationship with their organizations. It is also important to reveal the employee perceptions regarding these concepts in terms of uncovering the main reasons underlying the attitudes and behaviours of the employees and guiding the managers during the organizational development activities. In this study, the relationships between the teachers' perceptions regarding job motivation, organizational identification and administrative support were examined. These variables, whose effects on each other had been examined separately in the literature, were brought together with a dual model within the scope of this study. Based on the result of the model, it was concluded that perceived administrative support had a partial mediating role in the effect of job motivation on organizational identification. This study is limited to the variables of job motivation, organizational identification and perceived administrative support. In future studies, yhe relationship between the variables and different organizational behaviour elements can be examined. Moreover, this study in which quantitative research methodology is adopted, can be combined with qualitative research methods to further examine the underlying ideas of perceptions. 


\section{REFERENCES}

[1] M. Polat, "Örgütsel özdeşleşmenin öncülleri ve ardılları üzerine bir saha çalışması,” Uludağ Üniversitesi, 2009.

[2] M. G. Pratt, "To be or not to be? Central questions in organizational identification," in Identity in organizations: Developing theory through conversations, D. A. Whetten and P. C. Godfrey, Eds. Thousand Oaks, CA: SAGE Publications, pp. 171-207, 1998.

[3] D. T. Hall, B. Schneider, and H. T. Nygren, "Personal Factors in Organizational Identification," Adm. Sci. Q., vol. 15 , no. 2 , p. 176 , Jun 1970.

[4] T. Bentley, Takımınızın Yeteneklerini Geliştirmede İnsanları Motive Etme. İstanbul: Hayat Yayınları, 2000.

[5] H. Sercan, Etkili motivasyon yöntemleri. İstanbul: Etap Yayınevi, 2010.

[6] R. N. Lussier, Relations in Organizations: A Skill-Building Approach. Boston: McGraw-Hill Inc., 1996.

[7] S. P. Robbins, Orgazinational behavior: Concepts, Controversies, Application, Seven edit. Englewood Cliffs. NJ: Prentice Hall International. Inc., 1998.

[8] T. Koçel, İsletme Yöneticiliği. İstanbul: Beta Yayınları, 2010.

[9] L. W. Porter, G. A. Bigley, and R. M. Steers, Motivation and Work Behavior. New York: McGraw-Hill, 2003.

[10] R. Kanfer, "Motivation theory and industrial and organizational psychology," in Handbook of industrial and organizational Psychology, Second edi., M. D. Dunette and L. M. Hough, Eds. Palo Alto: CA: Consulting Psychologists Press, 1990.

[11] R. M. Steers, R. T. Mowday, and D. L. Shapiro, "The future of work motivation theory," Academy of Management Review, vol. 29, no. 3, pp. 379-387, 2004.

[12] M. Christen, G. Iyer, and D. Soberman, "Job Satisfaction, Job Performance, and Effort: A Reexamination Using Agency Theory," J. Mark., vol. 70, no. 1, pp. 137-150, Jan 2006.

[13] D. J. Houston, "Behavior in the Public Square," in Motivation in Public Management: The Call of Public Service, Oxford University Press, pp. 177-199, 2008.

[14] M. Patchen, Participation, achievement, and involvement on the job. New Jersey: Prentice-Hall, 1970.

[15] N. Hortaçsu, Ben Biz Siz Hepimiz: Toplumsal Kimlik ve Gruplar Arası İlişkiler. İstanbul: İmge kitabevi yayınları, 2007.

[16] F. Mael and B. E. Ashforth, "Alumni and their alma mater: A partial test of the reformulated model of organizational identification," J. Organ. Behav., vol. 13, no. 2, pp. 103-123, 1992.

[17] B. Buchanan, "Building Organizational Commitment: The Socialization of Managers in Work Organizations," Adm. Sci. Q., vol. 19, no. 4, pp. 533-546, Dec 1974.

[18] V. R. Lane and S. G. Scott, "The neural network model of organizational identification," Organ. Behav. Hum. Decis. Process., vol. 104, no. 2, pp. 175-192, Nov 2007.

[19] K. H. Karakuş, "Okul Yöneticilerinin Koçluk Rolleri İle Öğretmenlerin Örgütsel Özdeşleşme Düzeyleri Arasındaki İlişki," Pamukkale Üniversitesi, 2019.

[20] D. Bhanthumnavin, "Perceived social support from supervisor and group members' psychological and situational characteristics as predictors of subordinate performance in Thai work units," Hum. Resour. Dev. Q., vol. 14, no. 1, pp. 79-97, 2003.

[21] M. L. Broad, "Management Actions to support Tramsfer of Training," Train. Dev. J., vol. 36, no. 5, pp. 124-130, 1982.

[22] M. Zincirkiran, A. Yalçinsoy, and M. Işik, "Yönetici Desteği İle İş Memnuniyeti Arasındaki İlişsinin İncelenmesi," in 2nd International Congress on Economics and Business, pp. 976-983, 2016.

[23] E. A. Göktepe, "Algılanan Yönetici Desteği Ölçeği: Geliştirilmesi, Geçerliliği ve Güvenirliliği," İstanbul Üniversitesi İsletme Fakültesi Derg., vol. 46, Special Issue, pp. 31-48, 2017.

[24] N. D. Çakar and S. Yıldız, "Örgütsel Adaletin İş Tatmini Üzerindeki Etkisi: "Algılanan Örgütsel Destek "Bir Ara Değişken Mi?," Elektron. Sos. Bilim. Derg., vol. 8, no. 28, pp. 68-90, 2009.

[25] H. Özutku, V. Ağca, and E. Cevrioğlu, "Lider-Üye Etkileşim Teorisi Çerçevesinde, Yönetici-Ast Etkileşimi İle Örgütsel Bağlılık Boyutları ve İş Performansı Arasındaki İlişki: Ampirik Bir İnceleme,” Atatürk Üniversitesi İktisadi ve Ídari Bilim. Derg., vol. 22, no. 2, pp. 193-210, 2008.

[26] N. Öztürk, "Eğitim örgütlerinde örgüt kültürü ve öğretmen liderliği: Lider-üye etkileşiminin aracıllk rolü," Gaziantep Üniversitesi, 2015.

[27] F. Karcıoğlu and E. Türker, "Psikolojik Sözleşme ile Örgütsel Bağlılık İlişkisi: Sağlık Çalışanları Üzerine Bir Uygulama," Atatürk Üniversitesi İktisadi ve İdari Bilim. Derg., vol. 24, no. 2, pp. 121-140, 2010.

[28] H. M. Özgen and H. Özgen, "Psikolojik Sözleşme ve Boyutlarının İş Tatmini, Örgütsel Bağlılık ve İşten Ayrılma Niyetine Etkileri: Tıbbi Satış Temsilcileri Üzerinde Bir Araştırma,” Ç.Ü. Sos. Bilim. Enstitüsü Derg., vol. 19, no. 1, pp. 1-19, 2010.

[29] W. H. Turnley, M. C. Bolino, S. W. Lester, and J. M. Bloodgood, "The Impact of Psychological Contract Fulfillment on the Performance of In-Role and Organizational Citizenship Behaviors," J. Manage., vol. 29, no. 2, pp. 187-206, Apr 2003.

[30] B. J. Babin and J. S. Boles, "The effects of perceived co-worker involvement and supervisor support on service provider role stress, performance and job satisfaction," J. Retail., vol. 72, no. 1, pp. 57-75, 1996.

[31] F. Herzberg, "The motivation, hygiene concept and problems of manpower personnel administration," Pers. Adm., vol. 27, no. 1, pp. 3-7, 1964.

[32] E. Eren, Örgütsel davranış ve yönetim psikolojisi (7. baskl). İstanbul: Beta Yayınları, 2001.

[33] F. E. Öztay, "Eğitim örgütlerinde insan kaynakları yönetimi ile oluşturulmuş kurum kültürünün öğretmen motivasyonuna etkisi," Yeditepe Üniversitesi, 2006. 
[34] N. Karasar, Bilimsel Araştırma Yöntemi. 2015: Nobel Yayıncılık, 2015.

[35] F. Yılmaz, "Eğitim örgütlerinde örgüt kültürünün öğretmenlerin iş motivasyonu üzerindeki etkisi," Selçuk Üniversitesi, 2009.

[36] A. Loğa, "Çalışanların demografik özelliklerinin örgütsel özdeşim, örgütsel bağl1lık ve örgütsel vatandaşlık davranışına etkileri: Askeri birimlerde bir araştırma," Başkent Üniversitesi, 2003.

[37] A. Özdemir, "İlköğretim Okullarında Algılanan Yönetici Desteğinin ve Bireycilik-Ortaklaşa Davranışçılığın Örgütsel Vatandaşlık Davranışı ile İlişkisi 1," Kuram ve Uygulamada Eğitim Yönetimi, vol. 16, no. 1, pp. 93-112, 2010.

[38] Ş. Büyüköztürk, E. Kılıç Çakmak, Ö. Erkan Akgün, Ş. Karadeniz, and F. Demirel, Bilimsel araştırma yöntemleri. Ankara: Pegem Yayıncilık, 2017.

[39] D. N. Gujarati, Basic Econometrics, Fourth edition. New York City: McGraw-Hill, 2004.

[40] A. Balc1, Etkili okul ve okul geliştirme: Kuram uygulama ve araştırma. Ankara: Pegem A Yayınc1lı, 2007.

[41] A. De Rijk, N. Janssen, B. Van Lierop, K. Alexanderson, and F. Nijhuis, "A behavioral approach to RTW after sickness absence: The development of instruments for the assessment of motivational determinants, motivation and key actors' attitudes," Work, vol. 33, no. 3, pp. 273-285, 2009.

[42] H. Çalış, "Öğretmen motivasyonunda yönetici yaklaşımlarının incelenmesi kocaeli ili gölcük ilçesi örneği," Yeditepe Üniversitesi, 2012.

[43] G. Şekercioğlu and A. Çivilidă̆, "Çok Boyutlu İş Motivasyonu Ölçeğinin Türk Kültürüne Uyarlanması,” Mediterr. J. Humanit., vol. 7, no. 1, pp. 143-156, Jun 2017

[44] E. L. Deci and R. M. Ryan, "The 'what' and 'why' of goal pursuits: Human needs and the self-determination of behavior," Psychol. Inq., vol. 11, no. 4, pp. 227-268, 2000.

[45] T. L. P. Tang and H. Liu, "Love of Money and Unethical Behavior Intention: Does an Authentic Supervisor's Personal Integrity and Character (ASPIRE) Make a Difference?," J. Bus. Ethics, vol. 107, no. 3, pp. 295-312, May 2012.

[46] R. Eisenberger, F. Stinglhamber, C. Vandenberghe, I. L. Sucharski, and L. Rhoades, "Perceived supervisor support: Contributions to perceived organizational support and employee retention," J. Appl. Psychol., vol. 87, no. 3, pp. 565-573, 2002.

[47] E. Kurt, "Algılanan sosyal destek ve iş performansı ilişkisinde işe bağlılı̆̆ın aracı etkisi: Turizm işletmelerinde bir araştırma," Hacettepe Universitesi, 2013.

[48] Y. Demirhan, S. Kula, and G. Karagöz, "İş Memnuniyeti Ve Yönetici Desteğinin Memurlarin Performansina Etkisi: Diyarbakir Özel Harekat Polis Birimi Örneği,” Süleyman Demirel Üniversitesi İktisadi ve İdari Bilim. Fakültesi Derg., vol. 19, no. 1, pp. 285-297, 2014.

[49] R. Eisenberger, R. Huntington, S. Hutchison, and D. Sowa, "Perceived Organizational Support," J. Appl. Psychol., vol. 71, no. 3, pp. 500-507, Aug 1986.

[50] O. Çokluk, G. Şekercioglu, and Ş. Büyüköztürk, Sosyal bilimler icin cok degiskenli SPSS ve LISREL uygulamalari. Ankara: Pegem, 2012.

[51] C. Celep, Egitimde örgütsel adanma ve ögretmenler. Ankara: Anı Yayıncılık, 2000.

[52] A. Çakınberk, N. Derin, and E. T. Demirel, "Örgütsel Özdeşleşmenin Örgütsel Bağlllıkla Biçimlenmesi: Malatya ve Tunceli Özel Eğitim Kurumları Örneği,” İsletme Araştırmaları Derg., vol. 3, no. 1, pp. 89-121, 2011.

[53] E. S. Lee, T. Y. Park, and B. Koo, "Identifying organizational identification as a basis for attitudes and behaviors: A meta-analytic review," Psychol. Bull., vol. 141, no. 5, pp. 1049-1080, 2015.

[54] M. R. Edwards, "Organizational identification: A conceptual and operational review," International Journal of Management Reviews, vol. 7, no. 4. pp. 207-230, Dec 2005.

[55] K. Schermelleh-Engel, H. Moosbrugger, and H. Müller, "Evaluating the fit of structural equation models: Tests of significance and descriptive goodness-of-fit measures," MPR-online, vol. 8, no. 2, pp. 23-74, 2003. 